\title{
Description of Land Fragmentation in Latvia and its Prevention Opportunities
}

\author{
Dace Platonova*, Anda Jankava \\ Department of Land Management and Geodesy, LLU
}

\begin{abstract}
Already during the Land Reform, land properties of several land parcels were formed in the rural areas. Another factor that benefits to the fragmentation of farm properties is development of land market because buying or renting land for farm size building, it is not always possible to find adjacent land plot. Consequently, the land fragmentation not only makes land management difficult, but also increases the transport costs. With this rural land tenure system, competitive and efficient agricultural production cannot be discussed, so a large part of rural areas remains untreated. It was found that there is a strong correlation between the area of land parcels and their management - the smaller the area of a land parcel by the agricultural land, the greater the chance that it would not be managed, and vice versa, the greater the area, the more it is cultivated, that is, managed. Land consolidation is performed as the farm land use optimization activities in other countries. Land consolidation can be one of the efficient means for rural development, it can encourage formation of competitive agricultural production structure, giving farmers the opportunity to create holdings with a small number, but bigger size and better-shaped land plots. Thus, more income and opportunities to expand types of farming are created.
\end{abstract}

Key words: Size of farms, land parcels, land fragmentation, land consolidation.

\section{Introduction}

Land use opportunities, requirements and problems are changing with development of the state economics and welfare level of the people. Wherewith, the most part of the economical problems are not related to common land existence but rather with its concrete use. Joining European Union has influenced substantially Latvian agriculture determining both stronger requirements for production quality and conditions, and income level as well. Therefore, rational land use becomes more and more topical, which gives basic principles for long-term land management.

The farm land tenure structure of Latvia can be characterised as mostly consisting of farms that are small and often split into several separate land plots often located far from each other, not readily available and poorly located for agricultural purposes; as a result, it is difficult for the farmers to introduce new competitive production activities and use appropriate machinery (Platonova, \& Jankava, 2011). Many farmers are therefore forced to engage in production for just their own personal consumption, being unable to participate in the production for marketing purposes. This situation reinforces the trend of migration and abandonment of agricultural lands, especially in places situated far from the production sales sites.

A very important fact should be noted that life is becoming much more complicated in many rural regions because there is decrease in opportunities for the people to secure satisfactory existence for themselves both in agricultural and non-agricultural sectors. The formed situation can be grounded by many reasons; and the activities, aimed at life quality rising in rural areas, have to include simultaneously improvement of agricultural production, opportunities of entry into employment, improvement of infrastructure and lodging conditions, and protection of nature resources (Rivža, \& Krūzmētra, 2000). Within that complex development of rural regions, the land property structure that involves a lot of small and fragmented farms has to be taken into consideration.

Land use issues can be studied from many angles and for different purposes. Research of modern actual problems of land use can be found in many other scientific publications (Rivža, \& Ancāns, 2000; Jankava, 2003; Mičurova, 2004; etc.). 
Most of these authors point to the problem of uncompetitive small farm land areas and their fragmentation, driven by active land market. Land fragmentation makes land administration and management difficult, increases transport costs, so being not conducive to efficient use of land.

Consolidation is used as one of the measures for farmland usage optimisation abroad, which is known in Western Europe already since the end of the 18th century (Platonova, \& Jankava, 2011). Acquisition of experience of Western countries could help in solving of the situation. Within the methodological material prepared by UNO Food and Agriculture Organizations (FAO) on the designing of the land consolidation experimental project concept (Food and Agriculture ..., 2003), agricultural land consolidation is defined as the social, economical, juridical and technical event package which main basic aim, considering respect to the interests of residents, is:

- improvement of structure land properties;

- development of rural areas;

- consolidation of too fragmented land plots;

- increasing of the agricultural enterprises until their optimum sizes;

- implementation of modern technologies and techniques;

- developing of sustainable agricultural and socioeconomic infrastructure in countryside;

- nature protection and creation of sustainable ecosystems.

Land consolidation is sometimes understood incompletely just as a mere redistribution of land plots, which is performed to prevent consequences of land fragmentation. In fact, land consolidation is associated with major socio-economic reforms already since its initial implementation in Western Europe.

A number of other Central and Eastern European scientists have focussed on land consolidation studies (Hartvigsen, 2006; Horjan, 2011; Pasakarnis, \& Maliene, 2011; Maasikamäe, \& Mugu 2003; etc.). But there is just a little research, as well as practical experience, on the farm land consolidation in Latvian regions (Jankava, 2003).

In Latvia, the concept of land consolidation appeared in the 1990s of the last century. The first time it was included in the legislation by adopting the Law on Land Survey on September 14, 2006, in which land consolidation is included as one of the land survey project development tasks and is interpreted as package of implemented events proposed by individuals or legal persons, state or local municipality to optimize the land use in the public interest. However, further development of land consolidation has not yet been made in the legislation of Latvia.

Land consolidation can be one of the efficient means for rural development. It is of great vital importance in the agricultural development. Land consolidation can contribute to formation of competitive agricultural production structure, giving farmers the opportunity to create holdings with a small number but bigger size and better-shaped land plots, and to increase their total land areas. These considerations and conditions determined the aim of the research: to assess the need for land consolidation and its role in sustainable use of agricultural land.

Tasks to accomplish the aim are as follows: (1) to analyse the state of the farms by their area of agricultural land and land fragmentation; (2) basing on the foreign experience, to conduct a survey on land consolidation and its role in competitive farm building.

\section{Materials and Methods}

Within the research, data on economically active farms in Latvia were generalized from the Central Statistical Bureau (CSB) of the Republic of Latvia, particularly the years 2003, 2005, 2007, and 2010 (Lauksaimniecības skaitī̌sanas .., 2010; Lauku saimniecību ..., 2007). They are described as farms that are producing agricultural production independently of the amount of production and its way of use, or that keep good agricultural and environment conditions in the land.

According to the studies, all the farms in Latvia were subdivided conditionally into four groups: very small farms up to $2.4 \mathrm{ha}$, small farms from 2.5 to 9.9 ha, medium size ones $-10.0-49.9$ ha, and the large farms that exceed 50.0 ha. Analyzing in detail the latest results of agricultural census by CSB of the Republic of Latvia, grouping of farms by the agricultural land (AL) was conducted by determining the share of each size group by the number of farms and area.

Summarizing the State Land Service (SLS) State Real Estate Cadastre Information System (RESC) data (years 2001, 2006, and 2012), the registered properties containing land parcels with the real estate purpose of agriculture as the main economic activity were analyzed. It should be noted that the 


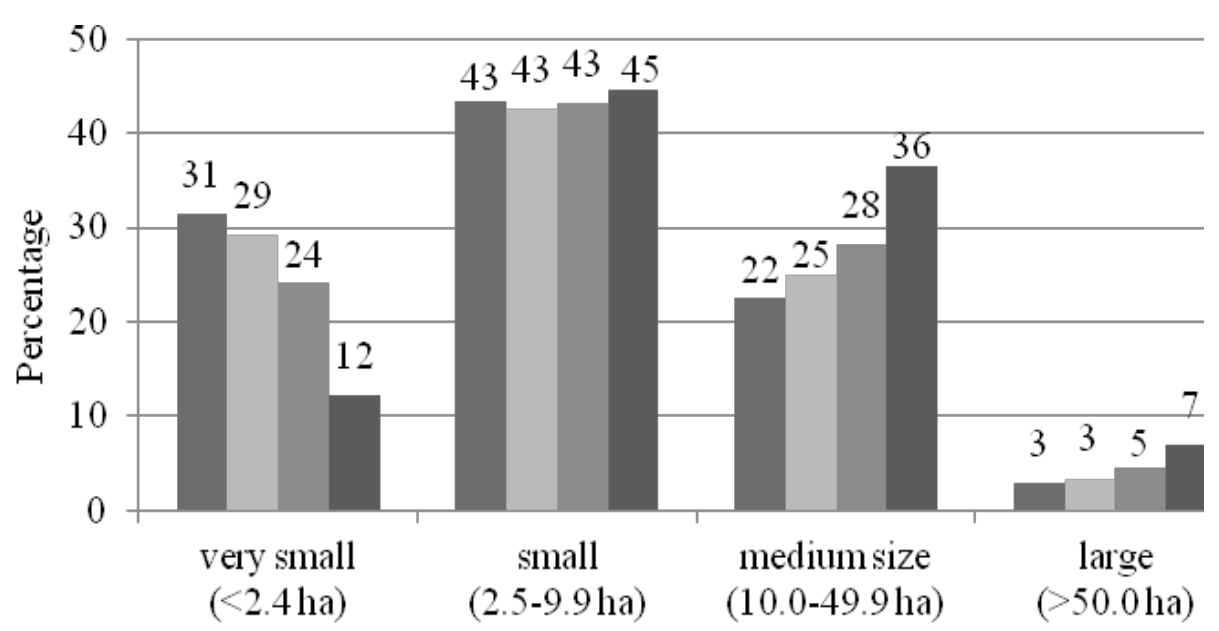

Farms

$2003 \quad \square 2005 \quad \square 2007 \quad \square 2010$

Source: data of the Central Statistical Bureau of Latvia (Lauku saimniecību ..., 2007; Lauksaimniecības skaitī̌sanas ..., 2010).

Fig. 1. Classification of Latvian farms by their area of utilized agricultural land.

information collected in 2012 is on the land parcels of size equal to or greater than two hectares (Nekustamā ipašuma ..., 2012) and so there may be differences between these data, broken down by the number of their land parcels.

Finding the correlation between areas of the land parcels and their management, analysis of surveys by the Rural Support Service (RSS) carried out in 2010 on all agricultural land (AL) parcels bigger than one hectare were analysed giving the status to the areas: cultivated or raw (Novadi un platību ..., 2010). According to the Part 8 of the Article 3 of the Law on Property Tax (Par nekustamā īpašuma ..., 1997), the land parcels (i.e. agricultural land which is not used for agricultural production or farming, including harvesting, grazing and keeping for farming purposes, or which is not maintained in good agricultural and environmental condition) considered to be a raw agricultural land were summarized. The Cabinet Regulation "Procedures for the Survey and Determining of the Raw Agricultural Area and Provision of Information on it" No. 635 gives the meaning - an agricultural area is not maintained in good agricultural and environmental condition if there has not been mowing, grass harvesting or crushing and dispersal done at least once due to the September 1 of the current year (Kārtība, kādā apseko ..., 2010).

In the research on the problems and elements, the monographic description, analysis and synthesis method were used, while the descriptive statistical analysis method was applied with data analysis.

\section{Results and Discussion}

Land use in agriculture occurs within particular farms, and the outputs depend not only on the work, materials, resources and soil fertility but also on the farm area and the mutual arrangement of the land parcels in use.

As the result of the Land Reform, most countries have developed structure of farm land unsuitable for modern European economic development. Land fragmentation and the small average size of farms are the result of land reform and privatization process not only in Latvia - similar processes are going on also in rural areas of our immediate neighbouring states Lithuania (Pasakarnis, \& Maliene, 2011) and Estonia (Maasikamäe, \& Mugu, 2003), as well as in other Eastern and Western European countries (Hartvigsen, 2006).

According to the authors' research, based on RL CSB data, in 2003, the average total area of agricultural land of a Latvian farm was 11.4 ha; besides, a third of the farms were of the land area less than 2.4 ha (Figure 1). One of the preconditions for this situation was that the land reform law did not name the minimum land area, as opposed to the 1920s-30s reform when future division of the existing and new rural land properties of less than 10 hectares was prohibited (Likums par zemes ..., 
Table 1

Classification of Latvian Farms by their Area of Utilized Agricultural Land in 2010

\begin{tabular}{lccccc}
\hline $\begin{array}{c}\text { Group } \\
\text { intervals, ha }\end{array}$ & $\begin{array}{c}\text { Number of } \\
\text { farms, thsd. }\end{array}$ & $\begin{array}{c}\text { \% of total } \\
\text { number of } \\
\text { farms }\end{array}$ & $\begin{array}{c}\text { Total utilized } \\
\text { agricultural area } \\
\text { (UAA), thsd. ha }\end{array}$ & $\begin{array}{c}\text { \% of utilized } \\
\text { agricultural area }\end{array}$ & $\begin{array}{c}\text { UAA on average } \\
\text { per farm, ha }\end{array}$ \\
\hline$<0.9$ & 2.6 & 3.1 & 1.1 & 0.1 & 0.4 \\
\hline $1.0-2.4$ & 7.5 & 9.0 & 12.9 & 0.7 & 1.7 \\
\hline $2.5-4.9$ & 14.3 & 17.2 & 52.7 & 2.7 & 3.7 \\
\hline $5.0-9.9$ & 22.7 & 27.3 & 162.9 & 8.4 & 7.2 \\
\hline $10.0-19.9$ & 19.3 & 23.2 & 269.3 & 13.9 & 14.0 \\
\hline $20.2-29.9$ & 6.5 & 7.8 & 157.0 & 5.1 & 24.2 \\
\hline $30.0-39.9$ & 2.9 & 3.5 & 99.6 & 3.9 & 44.5 \\
\hline $40.0-49.9$ & 1.7 & 2.0 & 75.7 & 10.7 & 68.6 \\
\hline $50.0-99.9$ & 3.0 & 3.6 & 207.8 & 10.5 & 137.9 \\
\hline $100.0-199.9$ & 1.5 & 1.8 & 202.7 & 35.8 & 558.1 \\
\hline$>200.0$ & 1.2 & 1.5 & 692.1 & 100.0 & - \\
\hline Total & 83.2 & 100.0 & 1933.8 & - & 23.2 \\
\hline Average & - & - & - & 5.2 & $2010)$ \\
\hline
\end{tabular}

Source: data of the Central Statistical Bureau of Latvia (Lauksaimniecības skaitī̌anas ..., 2010).

1937). Although, as it can be seen in Figure 1, over time the tendency of declining of very small farms and the increase in medium-sized and large farms can be observed (Figure 1). The reason is mainly due to the fact that because of the gradually more favourable treatment of agriculture in parallel with the land privatization process, land markets were developed, resulting in growing of farms through sale, lease or other transactions.

Describing the situation by the CSB latest agricultural census, in the farm organization by the areas of their agricultural land, it can be seen (Table 1) that the farms operate in total 1933.8 thousand ha of agricultural land and the average area per farm has increased to 23.2 ha. The compiled data show that since 2003, the number of very small farms $(<2.4$ ha) has decreased by $19 \%$, but the number of farms operating 10.0-49.9 ha has increased by $36 \%$. Despite the fact that only $6 \%$ of the total number of farms has the agricultural land area of more than 50 ha, their covered area is significant $-57 \%$.

In practice, forming of farms was affected by various objective and sometimes subjective factors, so farmland plots in property were developed on several land units, thus resulting in land fragmentation and inter-areas (Figure 2), although at the beginning of the reform, the legislation provided favourable territorial preconditions for successful development of agricultural production, recommending to form compact farms and to avoid inter-areas (Par Latvijas Republikas..., 1991). According to the information of the RL SLS on agricultural real estate percentage by the number of their constituting land parcels, it can be found that almost a half of them (41\%) are located on two to five land parcels.

No significant changes have happened over time - there are still agricultural real estate properties that are comprised of a number of land parcels (Figure 2), which in turn reduces the size of a land parcel and increases the land fragmentation problem. Figure 2 shows that the number of land parcels in a land property is increasing. The figure displays that by 2012 also the proportion of land located on a single land parcel without intersections has decreased. However, due to the fact that the aggregated data of 2012 are only on land holdings of the size equal to or greater than two hectares, it can be predicted that the land holdings of up to two hectares would mostly join the first and perhaps the second group, i.e. the land properties consisting of one or two land parcels. Non-observed land holdings (up to two hectares) comprise $58 \%$ of all agricultural land properties, so it can be said that over time the proportion of land holdings on a single land parcel has also increased. Also data of Paršova and 


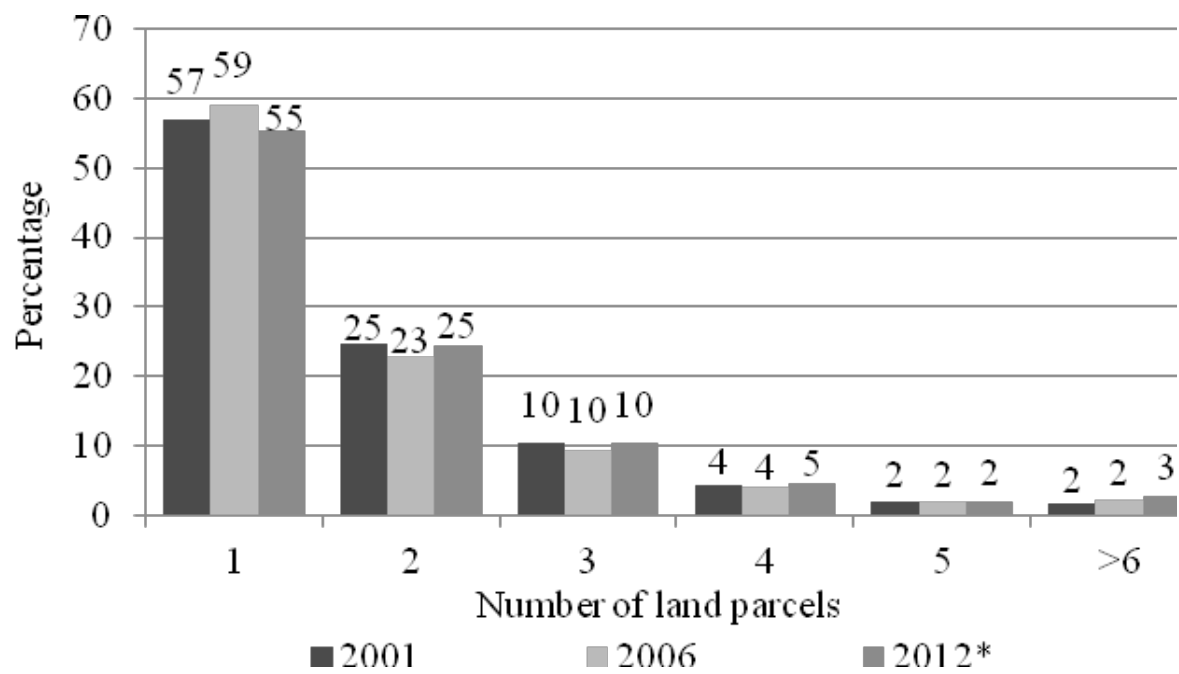

*only the land holdings of a size equal to or greater than two hectares are used in the analysis. Source: data of the State Land Service (Nekustamā īpašuma ..., 2012).

Fig. 2. Latvian agricultural real property distribution (\%) by the number of their land parcels.

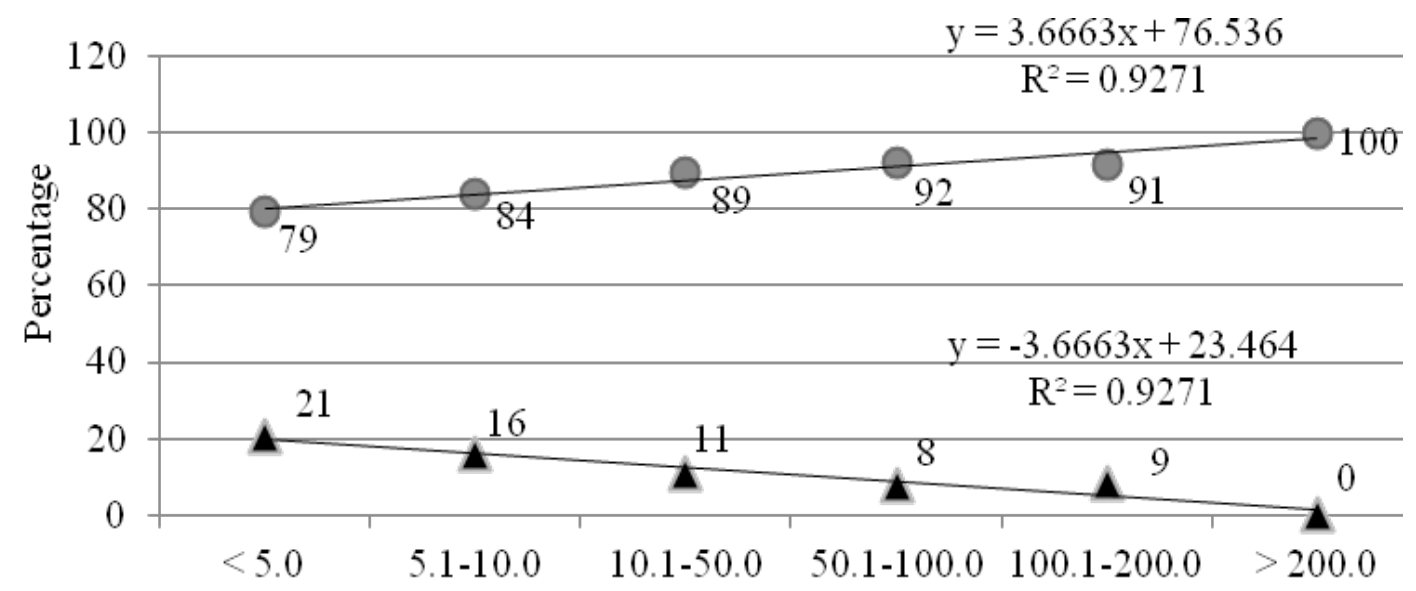

Hectares

\section{Ocultivated}

$\Delta$ raw

Source: data of the Rural Support Service (Novadi un platību ..., 2010).

Fig. 3. Grouping (\%) of the researched lands by the areas of their agricultural lands by November 3, 2010.

Kāpostinš (2012) on the Latvian real estate division by the number of land parcels confirm that $75 \%$ of the properties consist of a single land parcel.

However, the land markets are still promoting the land fragmentation. For instance, Daile Agro Ltd at Nākotne village of Glūda rural territory of Jelgava region of Zemgale district has 3500 ha management area of land including 1500 ha of property. Its neighbouring farm Ziemeli is managing 1560 ha including 360 ha of property. As the result of deals with the land, the areas of the farms have increased but also fragmentation of their land has grown because it is not always possible to own or lease adjacent lands. For example, the above farm lands consist of correspondingly 80 and 40 land parcels situated in various distances, the longest of which is $15 \mathrm{~km}$.

It has to be concluded that with this rural land tenure system, competitive and efficient agricultural production cannot be discussed, so a large part of rural areas remains untreated, as indicated by the surveys carried out by the RSS on land areas of all agricultural land parcels in 2010 (Figure 3). In total, $84 \%$ of all the agricultural land is cultivated and $16 \%$ remains raw in Latvia. Analysing these data, it can be found that there is a strong correlation 
(correlation coefficient $\mathrm{R}=0.96$ ) between the area of land parcels and their management - the smaller the area of a land parcel by the agricultural land, the greater the chance that it would not be managed, and vice versa, the greater the area of agricultural land, the more it is cultivated, that is, managed.

Agricultural land abandonment and fragmentation is not a problem just in our country, similar processes are going on also in rural areas of our immediate neighbouring states - Lithuania (Kavaliauskiene, \& Tarvydiene, 2011) and Estonia (Maasikamäe, \& Mugu, 2003) -, and in other Eastern and Western European countries (Horjan, 2011).

Specialist Miglavs (2003) of the National Institute of Agrarian Economics recognizes that the future main goals are considered to be sustainable use of agricultural land, ensuring improvement of land, preventing overgrowing of agricultural land, conservation of biodiversity of agricultural land, water and forest through sustainable management practices, as well as balanced development of rural and urban areas, promoting employment in rural areas and retaining the rural population.

In 2003, Miglavs opinion was that despite the fact that the land was then actively redeemed by foreigners and it could not be predicted who was going to own it after some years, it was important to use it productively, as there was one agricultural land hectare out of the four registered waiting for its productive use.

Rivža and Ancāns (2000) in the Latvian national report "The Essence of Rural Development: Towards Sustainable Integrated Rural Policy in Europe" rely on two basic principles, which can improve the situation in rural areas. The first one is the education and training of rural population, in order to obtain the necessary knowledge and experience. This, of course, will require all parties involved: government institutions, NGOs and political parties. Another one is the financial resources to make the sectors efficient (primarily agriculture and other sectors in the countryside), improve the infrastructure (rural roads and communications), social institutions (schools, medical care, etc.), and the environment, which according to the foreign experience (Food and Agriculture ..., 2003) is to be carried out through land consolidation.

Land consolidation can be a very efficient means for development of rural areas by opening up new opportunities for land managers to improve:
1) agricultural production (removing intersections, increasing income and reducing the hours spent working in the field);

2) more efficient management of natural resources:

- rationalization of land ownership structure can facilitate environmental protection and promote more rational planning and organization of a land property,

- land consolidation can contribute to the prevention of potential conflicts arising from the restructuring land for other types of its use;

3) development conditions of the rural area:

- in rural development, land consolidation can contribute to public and private investment in transport and communications networks, utilities, and increase of their profitability,

- contributing to rural renewal, land consolidation can stimulate social stability,

- in many Western European areas, where land consolidation is carried out, they mark growth of the newly created jobs, which in turn leads to increase in income tax,

- integrated land use planning on the spot and efficient coordination of all interests permit to avoid potential conflicts between economic growth stimulation of agriculture and the environment protection;

4) management systems of land resources. Land consolidation projects provide an opportunity to clarify and update information on property records.

In the literature and among experts there is a tendency to differentiate between land consolidation in a narrow sense (simple land consolidation) and land consolidation in a broader sense (comprehensive land consolidation or complex land consolidation). Another differentiation is between land consolidation executed voluntarily, on a legal base through a special law (possibly voluntary), or as a compulsory administrative procedure or legallyenforced land consolidation (Thomas, 2006). Many Eastern and Western European countries (Germany, Denmark, Lithuania, etc.) have a variety of land consolidation procedures defined in land consolidation strategy:

1) comprehensive land consolidation;

2) simplified land consolidation;

3) accelerated land consolidation;

4) voluntary land exchange;

5) land consolidation in case of permissible compulsory acquisition. 
Certain features of these methods of land consolidation abroad can be seen in the above methods (Jankava, 2003). The most widely applied farm land configuration improvement method in Latvia is land plots exchange or land border restructuring.

Of course, taking into consideration the current situation in the state, implementing of the land consolidation enterprises is not a cheap event for each land owner, therefore the state should support financially and legally planned elimination of the land fragmentation, regulating of borders and other processes related to the changes of the borders of the properties. Thus, united and compact property would be formed creating beneficial conditions for its efficient use.

\section{Conclusions}

Irrespective of large areas of agriculturally usable lands all over the territory of Latvia, properties of farmlands are generally small and fragmented, which is not characteristic to beneficial land use and its efficient management.

1. There is a strong correlation (correlation coefficient $\mathrm{R}=0.96$ ) between the area of land parcels and their management - the smaller the area of a land parcel by the agricultural land, the greater the chance that it would not be managed, and vice versa, the greater the area, the more it is cultivated, i.e., managed.

2. Over the past seven years, number of very small (up to 2.4 ha) farms has fallen by $19 \%$, and the number of farms (6\%) over 50 hectares has increased.

3. Central and Eastern European countries have developed good experience in land consolidation works; their experience shows that land consolidation can contribute to sustainable land use and development, increasing the land area and thus, creating a greater income, ways to develop the types of farming.

\section{References}

1. Food and Agriculture Organization of the United Nations. (2003). The Design of Land Consolidation Pilot Project in Central and Eastern Europe. Rome: FAO.

2. Hartvigsen, M. (2006). Land consolidation in Central and Eastern European countries. In Shaping the Change: XXIII FIG Congress, 8-13 October, 2006, Munich, Germany.
Retrieved from http://www.fig.net/pub/fig2006/ papers/ts71/ts71_04_hartvigsen_0882.pdf

3. Horjan, O. (2011). Consideraţii cu privire la studierea şi combaterea fenomenului de abandonare a terenurilor agricole. In Sisteme Informaţionale Geografice: Ediţia XIX, Simpozion Ştiinţific Internaţional, 6-8 October 2011 (pp. 128-136). Chişinău, Universitatea Agrară De Stat Din Moldova.

4. Jankava, A. (2003). Situation of land consolidation in Latvia. In Baltic Surveying 03: Transactions of the Estonian Agricultural University, 216, 48-55.

5. Kavaliauskiene, B., \& Tarvydiene, M.E. (2011). Problems and perspectives of land consolidation projects in the Republic of Lithuania. In Baltic Surveying 11: International Scientific Conference of Agriculture Universities of Baltic States, 11-13 May 2011 (pp. 91-98). Jelgava, Latvia: Latvia University of Agriculture.

6. Kārtība, kādā apseko un nosaka neapstrādātās lauksaimniecībā izmantojamās zemes platību un sniedz informāciju par to. MK noteikumi No. 635. (2010, July 29). Latvijas Vēstnesis, 2 pp.

7. Lauksaimniecības skaitīšanas rezultāti - 2010 . gada dati. (2010). LR CSP datu bāze: II Zemes izmantošana. Retrieved from http://data.csb. gov.lv/DATABASE/laukskait 10/ databasetree. asp?lang=16.

8. Lauku saimniecību struktūra - 2003., 2005., 2007. gads. (2007). LR CSP datu bāze. Retrieved from http://data.csb.gov.lv/DATABASE/ lauks/Ikgad\%C4\%93jie\%20statistikas\%20 dati/Lauksaimniec $\% \mathrm{C} 4 \% \mathrm{ABbas} \% 20$ strukt $\%$ C $5 \%$ ABra/Lauksaimniec\%C $4 \%$ ABbas $\% 20$ strukt $\% \mathrm{C} 5 \%$ ABra.asp.

9. Likums par zemes ierīcību. Lauksaimniecības nolikums. (1937). Rīga: Kodifikācijas nodaļas izdevums.

10. Maasikamäe, S., \& Mugu, E. (2003). Is there a need for land consolidation in Estonia. In Baltic Surveying 03: Transactions of the Estonian Agricultural University, 216, 23-32.

11. Mičurova, V. (2004, January 21). Zemes apsaimniekošanas problēmas Latvijā. Latvijas Vēstnesis. Retrieved from http://www.lanida.lv/ lv/information/press/archive/?id=27

12. Miglavs, A. (2003, November 14). Ir lietas, kas ir vērtības pašas par sevi. Agropols (Latvija ES, informatīvs izdevums lauku saimniekam par 
ES). Retrieved from http://www.agropols.lv/file s/\%5B2f9226d58e3657842ce4bea830e0b832\% 5DLatvija_ES_11_inetam.pdf

13. Nekustamā īpašuma valsts kadastra dati. (2012). Nekustamie īpašumi, kuru sastāvā esošai zemes vienībai ir noteikts nekustamā īpašuma lietošanas mērķis „,0101. Zeme, uz kuras galvenā saimnieciskā darbība ir lauksaimniecība”. [CD]. Rīga: VZD.

14. Novadi un platību grupas. (2010). Lauku atbalsta dienests. Retrieved from http://www.lad.gov.lv/ files/analize_pa_novadiem_un_platibu_grupam. xls.

15. Par Latvijas Republikas lauku apvidos realizējamās zemes reformas pirmās kārtas īstenošanu. Nolikums. (1991). Rīga: LR Augstākās Padomes Prezidijs.

16. Par nekustamā īpašuma nodokli. LR likums. (1997, June 17). Latvijas Vèstnesis, 17 pp.

17. Paršova, V., \& Kāpostiņš, E. (2012). Does land consolidation fit everywhere? In Knowing to Manage the Territory, Protect the Environment and Evaluate the Cultural Heritage: FIG Working Week 2012, 6-10 May, 2012, Rome, Italy. Retrieved from http:/www.fig.net/ pub/fig2012/papers/ts02e/TS02E_parsova_ kapostins_5795.pdf

18. Pasakarnis, G., \& Maliene, V. (2011). Land consolidation in Lithuania: Aspiration and actuality. In Environmental Engineering: The 8th International Conference, 19-20 May, 2011 (pp. 1424-1431). Vilnius, Lithuania: Vilnius Gediminas Technical University.

19. Platonova, D., \& Jankava, A. (2011). Research on the preconditions of land consolidation in rural districts. In Economic Science for Rural Development: Proceedings of the International Scientific Conference, No. 26, 28-29 April 2011 (pp. 174-181). Jelgava, Latvia: Latvia University of Agriculture.

20. Rivža, B., \& Ancāns, S. (2000). Lauku attīstības būtība: ceḷā uz ilgtspējīgu integrētu lauku politiku Eiropā. Organizāciju un institūciju attieksme pret lauku attīstību: Latvijas nacionālais ziņojums (pp. 1-42). Jelgava: LLU EF.

21. Rivža, B., \& Krūzmētra, M. (2000, November 2). Kad Eiropas lauku attīstības jaunā politika tieši skar arī Latviju. Latvijas Vēstnesis. Retrieved from http://news.lv/ Latvijas_Vestnesis/2000/11/02/Kad-Eiropaslauku-attistibas-jauna-politika-tiesi-skar-ariLatviju

22. Thomas, J. (2006). What's on regarding land consolidation in Europe? In Shaping the Change: XXIII FIG Congress, 8-13 October, 2006, Munich, Germany. Retrieved from http:// www.fig.net/pub/fig2006/papers/ts80/ts80_03_ thomas_0311.pdf

\section{Acknowledgements}

The academic study and the publication are financed by the project ", Support for Doctoral Studies Programme of Latvia University of Agriculture" /2009/0180/1DP/1.1.2.1.2/09/ IPIA/VIAA/017/. Agreement No. 04.4-08/ EF2.D1.02. 